\title{
Early Reading through Storytelling Activities
}

\author{
Kristi Nuraini \\ kristinuraini@yahoo.com \\ Universitas Muhammadiyah Jember
}

\begin{abstract}
Storytelling has been a part of children's life. They loved being told as well as telling a story. Being told a story made them see what has been read, and telling a story made them talk as they spoke it out. As the children learn a language, story is one effective way for them to learn a language. This study is aimed to find out to what extent storytelling could help young children with their early reading comprehension in terms of story-retell. One class in one national plus school has been the setting of the study with 13 students as the subjects. A mix method was implemented through a classroom action research design. This study came up with a significant result that storytelling activities have been effective ways to increase young children's retell fluency, both in content and fluency. The help of pictures, cue cards, and flashcards has been very efficient in helping young children to have a better comprehension in their early reading. These teaching aids had also been able to motivate them to be more active and engaged during the class.
\end{abstract}

Keywords; early reading, young children, storytelling

\section{INTRODUCTION}

Human beings possess the desire to have communication with others and we do this in many ways, through mimics, gestures; by moving parts of our body, and eventually words to represent our intention (Jackman, 2012). Words as a part of a language are not directly acquired once a baby is born, but it was gradually learnt as he grew older, through what he saw and listened to from the adults; parents or other members of family. A child will speak a language as other people around him; S/he acquires the language through the interaction with the other adults (parents and other family members). Language acquisition deals with a child's native language and is acquired naturally in everyday life, not necessarily to have it in formal education or schools (Krashen, 2000). He adds up that it focuses more on the message rather than forms or correctness of the language. It will put a child to a gradual process of listening to it and speaking it, then he learns how to use it by practicing it in everyday situations.

Before being able to produce language utterances, children required exposure for their language use, and reading ability is one skill a child needs to possess to be able to 
get their exposure. As a receptive skill, reading plays a crucial role in learning languages in early years. The first reason is that reading is the core of education and the basis of lifelong learning. If children can read they can accommodate themselves for getting and communicating information in their life. Second, reading is the essential skill a child needs to get in his later education. Reading is important for young children in kindergarten to prepare them for primary education. During the primary grades, they must master conventional reading (Copple, C., \& Bredekamp, 2009). And the most important is that literacy requires reading skills to accommodate young children with the ability to name the printed letters and sounds associated with printed letters as one of the ultimate goals of literacy mentioned that to become fluent and efficient readers who can make sense of and convey meaning in written language (National Early Literacy Panel, 2008).

Early childhood education can be a good place for young children to start to learn about reading. Parents, teachers, and caregivers can do some ways to promote reading in early years. They can prepare print rich environment such as by having labels, children books, signs, authentic pictures and literacy activities to get young children familiar with prints through book sharing or storytelling activities, reading the labels on the child's favorite snacks or story books between parents and children at home; teacher and children at school and caregivers and children at day care center. These will inevitably help young children with the experience to read (Jackman, 2012). Parents, teachers and caregivers can help young children get the meaning of the activities through interactions they built during the activities and scaffold things to mediate children to understand more easily (Isbell, 2002; MacDonald \& Figueredo, 2010; Morrow, 2002). That interaction can be built when children are having conversations with their parents, teachers, caregivers or other children as they talk and listen to each other; just like learning to read. Learning to read is learning to see, learning to listen; and learning to communicate (Brewer, 2007). Books can serve these experiences by letting the young children see how we hold it; how we read and sound out the printed words and make them comprehend those words through interactions with them. And storytelling is one way to get young children experienced with the book and the prints.

Numbers of research on storytelling revealed that storytelling is advantageous to help young children experiencing reading. First of all, as Isbell (2002)has discovered that it promotes expressive language development - in oral and written forms - and presents new vocabulary and complex language in a powerful form that inspires children to imitate 
the model they have experienced. In line with (Isbell, 2002), (Speaker, Taylor, \& Komen, 2004) also found that the language development of children, especially those experienced with storytelling will develop. They show improvement in reading skills in terms of vocabulary exposure. The language used in stories told in storytelling can promote authentic language development for the children who are being told or telling one (Gohsn, 2002; Isbell, 2002; Jackman, 2012). It helps children build vocabulary, utilize more complex sentences, and improve comprehension when frequently exposed and read to stories. In addition, storytelling is one way to enrich children's language experience as they learn through listening as well as telling a story, therefore, guidance by adults, parents, teachers and caregivers, are required to help young children in developing their language competence more rapidly (Bruce, 2014; Fast, 2014).

Furthermore, the vocabulary of the children is also increasing through the use of storytelling, either being told or telling one (Cooper, Capo, Mathes, \& Gray, 2007; Groce, 2004; Speaker et al., 2004), and acted as motivation for learning (Groce, 2004). Craig, Hull, Haggart, \& Crowder, 2001 added that through storytelling, children are served with contexts of literacy which can assist them to develop their ideas and also for their later reading comprehension and academic success.

Uncover the advantages of storytelling activities for young children; she is keen on having a careful study about it. As she had her preliminary study in the school, she prepared teaching aids and props to help young children comprehend the story better. Therefore she decided to take a thorough study on how storytelling activities could develop young children's early reading skills at preschool phase in kindergarten by providing more help in the form of teaching aids and props during the activities. Based on the previous studies on storytelling, she constructed a hypothesis that having storytelling activities with the help of teaching aids and props could develop young children's early reading skills.

\section{METHOD}

A preliminary study was done at one of private kindergartens in Jember. She observed the $\mathrm{K}-1$ classes and interviewed the class teachers. The observation was done in three weeks. The first one week, she acted as a non participant observer, while in the rest two weeks; she acted as participant observer as she taught the students storytelling activities by using big books, flashcards, and picture cards. During the observations, she found out two things. The first was that the teachers did the storytelling activity but they 
lacked teaching aids or props to help the young children understand and comprehend the story being told to them. The second was the teachers spoke quite fast and sometimes used quite complicated sentences which were beyond the children's level. These brought confusion to the children. Moreover, it was found that storytelling was no longer a painless way of learning for the children or painless way of teaching for the teacher. These gave even a tension when children were not able to comprehend the story when being asked a comprehension question. In the interview, she interviewed the class teachers to find out the data about the students' age, and language used by them. Also, she wanted to know how the storytelling activities were conducted in the school. From the interview, she found that the young children were having varied English competence due to their exposure of English outside the school. Some were quite proficient while others were not.

As the early findings were on two important things, she developed an action plan that was to provide teaching aids and props during the storytelling activities, and the second was to have it more slowly in delivering the story during the storytelling activities to assure young children's comprehension over the story being told. The teaching aids and props were prepared to help the "weak children" with their English exposure. She provided picture cards which were representing the vocabulary in the story being told. During the storytelling activities, she asked some comprehension questions to the children while telling the story and using the teaching aids and props to make them comprehend the story better. The subjects of this study were 13 students and two teachers in $\mathrm{K}-1$ Level in one private kindergarten in Jember, Indonesia. In this research, the writer also employed observation, interviews and tests called the Retell Fluency Test (RTF). The design of the research was Classroom Action Research (CAR) for its purpose is to find the most effective way of teaching in a particular classroom situation (Ary \& Jacobs, Lucy Cheser. Sorensen, 2010; Creswell, 2012). The test, RTF test was done to find out how well the students have been able to retell the story in terms of content and fluency.

The data were gathered from observation, interview, and RTF test. The data from the observation was taken from note taking and recording storytelling activities in the classroom. In order to get more insight on how teachers conducted the storytelling activities, interviews were also given to the class teachers. The data gathered from the observation and interview were synchronized to find out the preliminary results which determined the problems occurred in the classroom during the storytelling activities which hindered the young children's comprehension over the story and caused them to 
have the problems with the story comprehension. This helped the writer to design an action plan to overcome it. This was the time to begin the classroom action research (CAR) by implementing the action plan as the purpose of the study was to develop the young children's comprehension over the story, therefore CAR was chosen. The RTF test was taken to find out the improvement the young children have made through the help of teaching aids and props during the story telling activities. The results of the tests were analyzed and compared to see the improvement and decide whether it was necessary to revise the action plan or not.

\section{RESULTS AND ANALYSIS}

\section{RESULTS}

During the observation, the teachers and students were able to have their roles effectively to make the class run well. They used English as a means of communication which is the aim of the school. The teachers used simple English combining with gestures when communicating during the lesson. However, it was also found that during the storytelling activity, the teacher was only talking without having proper aids to clarify the concept of long and short. Moreover the teacher used vocabulary which was beyond the students' language level. This was in line with the result of the interview done with the class teachers' as they stated that during the storytelling activities in the classroom they usually provided some illustration, through sentences or simple drawing related to the story being told, yet, not enough aids were prepared to help the students to understand the story better. This has led the students into confusion. Besides teachers, students were also obliged to use English as a means of communication as well. They must use English when interacting with their peers and also with their teachers. They used English to ask and respond to the questions from both their peers and teachers. Once they did not know the English of a particular word, they were required to give a sign by putting their two hands above their head when saying the particular words.

In the interview, it was revealed that most of the students in the sample have been learning English in the school since they were 2 years old. It was also evident that some of the students had their families communicating in English in their everyday life. Therefore, some of the students were having enough exposure of English and their pronunciation and fluency were also quite good. In contrast, those who started to join the school at the age of 4 , and went directly to K-1 level, seemed to have difficulty in terms of their use of English as well as pronunciation. They tended to use their Bahasa Indonesia or mix English and Bahasa Indonesia when communicating during the lesson. 
Since English is the language of instructions in the school, the teachers always reminded the students to use English during the lesson. Of course, when they were having problems with their English, their teachers would assist them and remind them of the particular words they often forget.

The preliminary study has resulted in some findings that the teachers did have storytelling activities in conducting the learning process especially when they tried to present a new concept to the students. However, they did not provide enough aids to help the students to understand better about the desired topic. They were only telling the story in words; no pictures or props were prepared to clarify the meaning of some words in the story. This has led the writer to take some actions by conducting a CAR. The writer prepared two cycles to reach the desired result that is to help the young children with their fluency and story comprehension.

In the cycles, she decided to have four meetings. The Very Hungry Caterpillar was chosen to be the story to be told in the storytelling activities. She divided the story into two different topics within four meetings. The first two meetings were on days of the weeks and food the caterpillar ate each day, and the next two meetings were on the life cycles of a caterpillar. For the first topic, she prepared a simple picture story book in telling the story and the number of flashcards represented the vocabulary in the story. These included names of the days, food the caterpillar ate each day based on the number of the items in the story, pictures of the phases of metamorphosis and other related vocabulary found in the story. In meeting one and two, with all the aids she has prepared, she told the story and requested the young children to post the flashcards on the board based on the story being told. The young children were asked to post the name of the days in a week and also the food the caterpillar ate each day as she told the story slowly as the children were posting the flashcard onto the board. The outcome was that they were able to follow the storyline more easily, yet they still could not initiate in retelling the story. At the end of meeting two, after recalling the story, the students were asked to do a simple worksheet to match the day and the food the caterpillar ate. Still with the flashcards posted on the wall, they were asked some comprehension questions related to the story and answered the questions using the flashcards provided. In meeting three and four, the writer reviewed the story of The Very Hungry Caterpillar, but this time, she focused on the life cycle of the caterpillar. She provided the flashcards representing the stages of the changes a caterpillar has undergone in its life cycle to help 
percentage showed that in term of content, the students' comprehension in their emergent reading has improved for their achievement shows that more students were having very good category than good or fair. Figure 3 below, gave us clear evidence on the progression of the students fluency in retelling the story. The results of RTF test 1, 2 and 3 in fluency reveal the gradual improvement on their fluency.

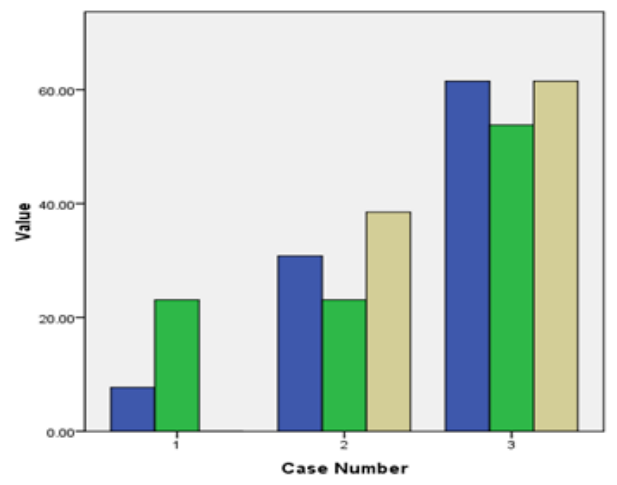

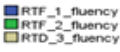

Figure 3. RTF Tests Results in story fluency

Figure 3 shows for the fair category, RTF test 2 got a higher percentage compared to RTF test 1 with $23.8 \%$ for RTF 2 and $7.7 \%$ for RTF 1 while there was $0 \%$ for RTF test 3. There was an increase in percent for good categories. RTF test 1 with $30.8 \%$, RTF test 2 with $23.1 \%$ and RTF test 3 with the highest percentage of $38.5 \%$. Very good category also showed improvement, but there was a little drop in percentage in RTF test 2 with $53.8 \%$ as it gained its improvement again in RTF test 3 with $61.5 \%$. The overall percentage results in fluency showed that the students' comprehension in their emergent reading has improved for their achievement shows that in the end, more students were having good and very good categories with no one for the fair category.

\section{DISCUSSION}

The progression over the content and fluency in retelling the story was caused by the students' familiarity with the use of English. Meanwhile the help of storytelling activities with picture books and flashcards (props) has been a media to boost their ability to have a better comprehension and retention of vocabulary used in the story since the story was told in their language capacity. As the principles suggested by (Trestle-Brand \& Donato, 2001) and (Bryant, 2009) that once the teller knows how to deliver the story, he will be able to make use of any aids, including language simplification and the use of props to make the story more realistic to the audience. Also during the research, the writer has tried to build good communication with the students, so that when conducting the storytelling activities with them, she can manage to have good interaction with the 
students. The interaction and communication done by the teachers and the young children during the storytelling activities has helped them to build good rapport as Brewer (2007) suggested that interaction in telling story between teacher and young children helped the young children with the exposure of the target language and it indeed assisted them to be a better communicator when having interaction with both their teachers and their peers. They also become more confident with what they said when retelling the story. Groce (2004) mentioned that the use of gestures when telling the stories can help maintain the interaction and eye contact between learners and the teller. Therefore, when some students were having problems with the story, the writer could manage to overcome the problems. Having picture books and flashcards also helped her to reduce the students' difficulty in understanding the storyline of the story. This has motivated the students to have good rapport with the writer as the teller so that they were confident and comfortable during the activities, especially when they were asked to retell the story. Isbell (2002) added that storytelling activities modeled young children with the language learned in the target language so that they could communicate as the target language has modeled as they imitate the language they have heard during the storytelling activities. This was in line with Speaker, Taylor, and Komen (2004) that the language the children used will develop through the experience they have with storytelling. During the storytelling activities with the writer, it was found out that they were being helped with the teaching aids and props prepared in the activities. This has made the learning become more fun and relaxing for the young children as Groce (2004) has revealed that storytelling activities could make learning more effective and enjoyable. During the storytelling activities the writer also found that storytelling activities have increased young children's interest rather than reading from a textbook. Having a picture book and some flashcards (props) have made the students feel like they were playing with the story, they tried to make use of the flashcards to help them with the vocabulary used in the story so that when retelling it, they could recall the story more easily.

Furthermore the result of the study has revealed that storytelling activities with the use of teaching aids and props has helped young children to improve their vocabulary as Cooper et al., (2007) have also proven that storytelling helped to improve children's knowledge of vocabulary for both English learners and Native English learners. To do so, teachers and caregivers, are required to help young children in developing their language competence more rapidly (Bruce, 2014; Fast, 2014) this is especially required when the learners are non-native learners as we also had in this study in which the young children in the class were all non-native learners of English. In other words, it can be said that 
storytelling has a good impact on vocabulary knowledge for both native and non native learners of English. This practically meant that their comprehension was also increasing with their better understanding of the vocabulary used throughout the story. As a result, it has helped them to be able to retell the story in a more fluent manner as they have had better comprehension over the story being told.

\section{CONCLUSION}

Engaging young children with reading in their early ages will help them with their future educational stages they need to undergo. As the early reading activity, children are introduced to more relaxing and fun activities one of which is through storytelling activities. Through storytelling activities, young children learn to recognize symbols of language. With the help of teaching aids in the form of picture books and flashcards, teachers could enrich young children's exposure to the target language being learned and communicate their understanding on the content of the story. As teachers, we are demanded to be aware of what they need and be creative and innovative to prepare what is necessary to help their learning. Preparing a fun and enjoyable atmosphere by providing help and assistance during the story telling activities could help young children with their language development in terms of their vocabulary mastery and story comprehension. These two elements could lead them to be better and fluent in communicating their understanding over the story being told as they retell it which will prepare them for more reading skills as they continue the next stages of their education. Having better vocabulary retention and comprehension helps the young children with the story comprehension in terms of its content and ways of retelling it. In short, storytelling is one powerful and meaningful way a teacher can communicate with children using narrative forms by utilizing props, vocalization, body language and facial expression to help children in comprehension in their emergent reading.

\section{REFERENCES}

Ary, D., \& Jacobs, Lucy Cheser. Sorensen, C. K. (2010). Introduction to Research in Education (8th Edition). Canada: Cengage Learning.

Brewer, J. A. (2007). Introduction to Early Childhood Education: Preschool through Primary Grades (6th Edition). Boston: Allyn and Bacon.

Bruce, B. (2014). Introduktion: Berättande i förskolan. 1. utg. Stockholm. In Nature \& Culture

(pp.

12-16).

ADJES Vol.7, No. 1, March 2020 : 7-17 
Bryant, C. S. (2009). How to Tell Stories to Children: And Some Stories to Tell. (T. F. Press, Ed.).

Cooper, P. M., Capo, K., Mathes, B., \& Gray, L. (2007). One Authentic Early Literacy Practice and Three Standardized Tests: Can a Storytelling Curriculum Measure Up? Journal of Early Childhood Teacher Education, 28(3), 251-275. https://doi.org/10.1080/10901020701555564

Copple, C., \& Bredekamp, S. (Ed.). (2009). Developmentally Appropriate Practice in Early Childhood Programs (3rd Edition). Washington DC: NAEYC.

Craig, S., Hull, K., Haggart, A. G., \& Crowder, E. (2001). Storytelling: Addressing the Literacy Needs of Diverse Learners. Teaching Exceptional Children, 33, 46-51.

Creswell, J. W. (2012). Educational Research: Planning, Conducting, and Evaluating Quantitative and Qualitative Research (4th Edition). Boston: Pearson Education, Inc.

Fast, C. (2014). Berättande i förskolan.Tysta! Jag Vill beratta.1.utg.Stockholm. In Nature \& Culture 2 (pp. 29-50).

Gohsn, L. . (2002). Four Good Reasons to Use Literature in Primary School ELT. Oxford: Oxford University Press.

Groce, R. D. (2004). An Experimental Study of Elementary Teachers with the Storytelling Process: Interdisciplinary Benefits Associated with Teacher Training and Classroom Integration. Reading Improvement, 41(2), 122-128.

Isbell, R. T. (2002, March). Telling and Retelling Stories: Learning Language and Literacy. Young Children, 26-30. Retrieved from http://www.naeyc.org/yc/files/yc/file/200203/Isbell_article_March_2002.pdf

Jackman, H. L. (2012). Early Education Curriculum: A Child's Connection to the World (5th Edition). Delmar, USA: Cengage Learning Library of Congress.

Krashen, S. D. (2000). What Does It Take to Acquire Language? ESL Magazine 3, 22-23.

MacDonald, C., \& Figueredo, L. (2010). Closing the Gap Early: Implementing a Literacy Intervention for At-Risk Kindergartners in Urban Schools. The Reading Teacher, 63(5), 404-419. https://doi.org/10.1598/RT.63.5.6

Morrow, L. M. (2002). The Literacy Center: Contexts for Reading and Writing. Maine: Stenhouse Publishers.

National Early Literacy Panel. (2008). Developing Early Literacy: A Scientific Synthesis of Early Literacy Development and Implications for Interventions.

Speaker, K. M., Taylor, D., \& Komen, R. (2004). Storytelling: Enhancing Language Acquisition in Young Children. Education, 125, 13-14.

Trestle-Brand, S. T., \& Donato, J. M. (2001). Storytelling in Emergent Literacy: Fostering Multiple Intelligences. Delmar, USA: Thomson Learning. 